
\title{
CIÊNCIA'NATURA
}

\section{MICROBIAL POOL FOR BIOLOGICAL CONTROL OF MILK QUALITY AND PATHOGEN PROFILE OF MILK FROM A DAIRY FARM IN SOUTHERN BRAZIL}

${ }^{1}$ Pamela Lais Cabral Silva, ${ }^{1}$ Thayli Ramires Araújo, ${ }^{1}$ Lucas Guidoni, ${ }^{1}$ Fernanda Gonçalves, ${ }^{2}$ Roger Marques, ${ }^{1}$ Lauren Vieira, ${ }^{1}$ Luciara Corrêa e ${ }^{1}$ Érico Corrêa

\begin{abstract}
The objective of this study was to assess the health and environmental profile milk from a local dairy farm by applying a microbial pool of Bacillus cereus, Bacillus subtilis, Bacillus licheniformis, Bacillus amyloliquefaciens, Lactococcus lactis subsp. lactis in different environments. The inoculum used was diluted with water and then sprinkled on the surface of predetermined sites for characterization. Five swab samples from the ground were collected at random from the room or environment. Populations of the total and fecal coliforms, Salmonella spp., Staphylococcus coagulase positive and sulfite reducing Clostridium were set as indicators of hygiene and sanitary conditions. Milk samples were also collected from the cooling tank. Somatic cell counts (SCC), Somatic cell counts (SCC), fat, protein, lactose and milk total solids were determined parameters were determined, we used the methods set by ANVISA. A statistically significant reduction of SCC $(P<0.05)$ was observed from 2.8 to 2.0 log SSC. $\mathrm{L}^{-1}$, significant interactions were considered when the probability was lower than $5 \%$. The inoculum also showed a highly significant effect on pathogen populations, especially on Salmonella spp. and sulfite reducing Clostridium, while a lower reduction on the other two pathogens. In this way, the inoculum was effective in reducing pathogen populations, improved the sanitary quality, thus it might be used as a prevention tool for the diseases with environmental origin in dairy farms.
\end{abstract}

Keywords: Mastitis. Enterobacteria. Sanitation control 


\section{Introduction}

Milk is a relatively cheap source of nutrients having a high intake in developing countries (MÜLLER, 2002) therefore, milk quality needs to be assessed in order to ensure consumer safety. In Brazil, milk quality related to the livestock health has great impact on the productivity. Somatic cell count (SCC) is a useful predictor of intra mammary infection (IMI) that includes $75 \%$ leucocytes (neutrophils, macrophages, lymphocytes, erythrocytes) and 25\% epithelial cells. High SCC has a negative influence on the quality of raw milk and is related to changes in milk consistency (density), low protein and high risk for milk hygiene, since it might even contain pathogenic organisms (SHARMA, SHINGH \& BHADWAL, 2011). In addition, high SSC also results in reduced productivity of a herd, as an animal cannot be milked until it is completely recovered. The impact of this problem in the Brazilian herds is about $17.45 \%$ in clinical and $72.56 \%$ in subclinical settings (LADEIRA, 2001). These mastitis episodes are regularly associated with the presence of Enterobacteriaceae and the main source of this strain is the gastrointestinal tract (LEVY, 2004). Thermotolerant coliforms, Staphylococcus and Salmonella spp., are important indicators of hygiene and sanitary conditions since they are directly linked to good hygiene practices and presence of infectious bacterium (SANTOS et al., 2010).

Dairy facilities are at a greater risk for environmental mastitis than the cows on pasture at the time of milking. Sources of environmental pathogens include manure, bedding, feedstuffs, dust, dirt, mud, and water. Even in semi-confinement regime, the flock is exposed to various threats. The lack of proper sanity at the milking and feeding sites associated with high density of animals promotes the occurrence and spread of the diseases caused by the pathogens normally found in animal excreta. Thus, it is essential to ensure good hygienic and sanitary conditions, so that the health of the herd can be assured (RADOSTITS et al., 2002).

Usually the household cleaning products are used to perform sterilization. However, these chemicals are detrimental to the environment, since they are mostly not biodegradable (BRASIL, 1988). In consequent, water resources lose capability of self-purification when contaminated by these products.

An alternative to reduce or eliminate such pathogens in dairy environment is the use of an inoculum in pavements sites. The inoculum contains one or more kinds of non-pathogenic bacteria and dispersing agents, which indirectly control the population of pathogens mainly by increasing competition for subsistence. This method is usually implied in waste biological treatment systems with an objective to eliminate organic matter, and thus promotes an environmental competition for the substratum between the microorganisms naturally present in the waste. This biological control may also produce secondary metabolites that are bactericidal and/or bacteriostatic helping in control of certain microbial species (XAVIER \& LUCAS, 2010).

Antagonistic bacteria have been reported as a potential alternative to inhibit pathogens instead of administering antibiotics. In related studies, Bacillus cereus, Bacillus subtilis and Bacillus amyloliquefaciens proved as excellent antagonistic agents of gram-positive bacteria, playing the role of inhibitors forth pathogenic species, producing antibiotics like surfactin, fungycin e iturin (LEE et al., 2010). Another bacterium that had its antagonistic effects studied is the Bacillus licheniformis, a lactic-acid bacterium considered as a probiotic due to a production of inhibitory peptidic substances forth pathogens and spoilage bacterium (CLADERA-OLIVEIRA, CARON \& BRANDELLI, 2004; SHOBHARANI, PADMAJA \& HALAMI, 2015). Another antimicrobial agent that can act as a probiotic for producing metabolites such as lactic acid, diacetyl, carbon dioxide, hydrogen peroxide and bacteriocins, is the Lactococcus lactis subsp. lactis which showed a potential for opposing the growth of bacteria such as Salmonella spp., Staphylococcus aureus (KHALID et al., 2011).

In this way, the aim of this study was to apply a pool of microorganisms on the floor of a milk cattle farm, evaluating its effects on the sanitation quality and overall quality of the milk produced on the property.

\section{Materials and Methods}

\subsection{Microbial Pool Application}

The microbial pool consisted of Bacillus cereus, Bacillus subtilis, Bacillus licheniformis, Bacillus amyloliquefaciens, Lactococcus lactis subsp. lactis in a concentration higher than 1,25x108 CFU.g-1, sodium bicarbonate, sodium chloride and wheat bran; every component of a commercial product granted to the Laboratory of Wastes from the Universidade Federal de Pelotas (UFPel) to evaluate their antagonistic effect.

The application was carried out using a simple dilution with deionized water to reach a concentration of $71.4 \mathrm{mg} . \mathrm{L}^{-1} . \mathrm{cow}^{-1}$, followed by direct spraying onto the farms flooring, weekly reaching a total of 60 days.

\subsection{Sampling}

The milk and flooring samples were collected in a milk cattle farm, with a lot of 20 cows with a two milkings routine each day. The experiment included the calf stables with three animals with approximately 30 days of age each. The farm was located 
in south of Rio Grande do Sul State and the cattle-management system was characterized by the pasture feed during summer. Three collection spots were defined to application and sampling: feeding square, pre-milking room and heifer rearing. The flooring was a slick concrete paving.

Five environmental samples per site were collected from random points by using a swab dipped in sterilized saline solution. Milk samples were also collected directly from milk cooling tank in the bronopol milk sample preservative (2-bromo-2-nitropropane-1,3-diol), with a 3 hours period between the milking and sample collection. All samples were stored and transported in insulated box with ice to the laboratory of wastes where the analytical procedures began within two hours of sampling.

\subsection{Microbiological Analysis}

For hygienic and sanitary characterization populations of total and thermotolerant coliforms, Salmonella spp., Staphylococcus coagulase positive and Clostridium were evaluated using a methodology recommended by the American Public and Health Association (APHA, 2001).

\subsection{Milk Analysis}

The data were analyzed for normality by the Shapiro-Wilk test, homoscedasticity by Hartley test and the independence of the waste by graphical analysis. For the somatic cell count and physicochemical characterization of the milk, we used the methods set by ANVISA (BRASIL, 2001). The determination of fat, solids, protein and lactose was carried out by absorption spectrometry method in the mid-infrared (MID) region; wherein the transmittance rate is measured to identify the organic compound.

\subsection{Statistical Analysis}

The experiment followed a fully randomized design with three repetitions and one factorial arrangement in which the factors were inoculum applications (before and after application). The milk samples were evaluated for fat, protein, lactose, milk total solids, and SCC. The manure samples were evaluated for microbial profiles.

After that, the data were subjected to analysis of variance $(\mathrm{P} \leq 0.05)$. In case of statistical significance T-test was applied $(\mathrm{P} \leq 0.05)$. Significant interactions were considered when the probability was lower than $5 \%$.

\section{Results and Discussions}

The results of milk evaluation tests are shown in Table 1. With the exception of fat, all other milk components were affected by the inoculum application.

Table 1 - Milk constituents and SCC before and after inoculum applications.

\begin{tabular}{c|c|c}
\hline Treatment & BIA & AIA \\
\hline Fat (\%) & $4.07 \mathrm{~ns}$ & 4.08 \\
\hline Protein (\%) & $3.52 \mathrm{a}$ & $3.04 \mathrm{~b}$ \\
\hline Lactose (\%) & $4.38 \mathrm{a}$ & $4.23 \mathrm{~b}$ \\
\hline Milk Total Solids (\%) & $13.20 \mathrm{a}$ & $12.27 \mathrm{~b}$ \\
\hline SCC $(105 \mathrm{cs} / \mathrm{mL})$ & $2.8 \mathrm{a}$ & $2.0 \mathrm{~b}$ \\
\hline
\end{tabular}

${ }^{n s}$ Means $(n=7)$ without significant difference in $F$ test $(p<0.05)$. Means in lines followed by different letters show statistically significant difference between the treatments $(p<0.05)$. BIA means before treatment, AIA means after treatment and SCC means somatic cell count.

The protein showed a decrease of $13.64 \%$, lactose of $3.42 \%$, total solids of $7.04 \%$, while the parameter, somatic cells, showed most significant decrease of $28.57 \%$.

It's well known that few factors other than infection status have a significant impact on milk SCC and composition (HARMON, 1994), where it's possible to attribute the changes in milk profile to a reduction of the environmental pathogens. According to ICAR (2011), normal cow milk contains between 50,000 and 200,000 somatic cell/mL, which leads to categorize the milk of BIA under the hygiene-quality standards. Since the environmental pathogens often associated with SCC increase include the coliforms and environmental streptococci and enterococci (DUFOUR, 2011), it's possible to attribute the results to a competition between microorganisms (environmental pathogens versus inoculum microorganisms). High SCC milk shows a decrease in casein, fat and lactose (SABEDOT et al., 2014), thus the reduction observed in this trial can be attribute to SCC 
decrease, an indirect effect of inoculum application, on the health of cows that are in milk production, allowing a better use of energy and nutrients by the animals. It is well know that a reduction in milk components affects product yield in its industrialization, being undesirable by the dairy industry. Additionally pay for higher fat and protein is already a reality in Brazil (REIS et al., 2007) influencing the income of the milk producer.

The Normative Instruction 51, established by Agriculture, Livestock and Development Ministry (BRASIL, 2011) define the minimum values for fat, protein and defatted solids in $3 \%, 2 \%$ and $8.4 \%$, respectively. In this case, both treatments were within the standards.

Table 2 - indicates the results of effectiveness on inoculum application at different places in the dairy cattle farm.

\begin{tabular}{|c|c|c|c|c|c|}
\hline Treatment & $\begin{array}{l}\text { Total Coliforms (log } \\
\text { MNP.mL-1) }\end{array}$ & $\begin{array}{l}\text { Thermotolerant } \\
\text { Coliforms } \\
\text { (log MNP.mL-1) }\end{array}$ & $\begin{array}{c}\text { Clostridium } \\
\text { (log MNP.mL-1) }\end{array}$ & $\begin{array}{c}\text { Staphylococcus (log } \\
\text { CFU.mL-1) }\end{array}$ & Salmonella spp. \\
\hline \multicolumn{6}{|c|}{ Feeding square (FS) } \\
\hline BIA & $5.12 \mathrm{a}$ & $4,90 \mathrm{a}$ & $5.20 \mathrm{a}$ & $\mathrm{N} / \mathrm{D}$ & $\mathrm{A}$ \\
\hline AIA & $3.09 \mathrm{~b}$ & $2,96 b$ & $0.40 \mathrm{~b}$ & $\mathrm{~N} / \mathrm{D}$ & A \\
\hline \multicolumn{6}{|c|}{ Pre-milking room (PMR) } \\
\hline BIA & $4.86 \mathrm{a}$ & $4.43 \mathrm{a}$ & $\mathrm{N} / \mathrm{D}$ & $3.45 \mathrm{~ns}$ & $\mathrm{P}$ \\
\hline AIA & $3.14 \mathrm{~b}$ & $3.10 \mathrm{~b}$ & $\mathrm{~N} / \mathrm{D}$ & 2.71 & A \\
\hline \multicolumn{6}{|c|}{ Heifer rearing $(\mathrm{HR})$} \\
\hline BIA & $5.38 \mathrm{a}$ & $3.31 \mathrm{~ns}$ & $\mathrm{~N} / \mathrm{D}$ & $4,23 a$ & $\mathrm{P}$ \\
\hline AIA & $3.21 \mathrm{~b}$ & 3.18 & $\mathrm{~N} / \mathrm{D}$ & $3,13 b$ & $\mathrm{~A}$ \\
\hline
\end{tabular}

ns Means $(n=7)$ without significant difference in $F$ test $(p<0.05)$. Means in lines followed by different letters show statistically significant difference between the treatments $(p<0.05)$. BIA means before treatment, AIA means after treatment, $\mathrm{P}$ means presence and A means absence.

In microbiological analysis, a decline in total and thermotolerant coliform populations as well as Clostridium was observed at FS site Table 2. At PMR site, we observed a decline of $39.6 \%(\mathrm{P}<0.05)$ in populations of total coliforms, and the thermotolerant coliforms were reduced from 5.12 and 4.90MPN.mL ${ }^{-1} \log$ for 3.09 and $2.96 \log$ CFU. $\mathrm{mL}^{-1}$ respectively. An analysis of the sulfite reducing Clostridium showed the presence of $5.20 \log$ CFU.mL ${ }^{-1}$ without the addition of inoculum, and this value reduced by $92.3 \%(\mathrm{P}<0.05)$ to $0.40 \log \mathrm{CFU} \cdot \mathrm{mL}^{-1}$ after addition of the inoculum; however, we did not detect a positive Staphylococcus coagulase test and Salmonella spp. In FS, the Staphylococcus population showed no significant reduction $(\mathrm{P}>0.05)$ after addition of the inoculum; this trend was contrary to the total coliform count that decreased by $35.4 \%$ MPN. $\mathrm{mL}^{-1}$. This same enclosure verified the presence of $3.1 \log$ MPN.mL1 thermotolerant coliforms after the treatment with sulfite reducing Clostridium inoculum. Total coliforms and coagulase positive Staphylococcus presented an initial population of 5.48 $\log$ MPN.mL ${ }^{-1}$ and $4.23 \log$ CFU.mL $L^{-1}$, respectively, before the treatment; which reduced to $3.21 \log$ MPN.mL ${ }^{-1}(\mathrm{P}<0.05)$ and $3.13 \log \mathrm{CFU} \cdot \mathrm{mL}^{-1}(\mathrm{P}>0.05)$, respectively. On the other hand, the fecal coliforms were not significantly reduced when exposed to inoculum $(\mathrm{P}>0.05)$.

The decrease in pathogen counting suggested that the inoculum acted efficiently at the most important places, probably by inhibiting the growth of pathogenic microorganisms by competitive mechanisms for substratum or nutrients. In addition to these factors, some studies have indicated that secondary metabolites are produced, which affect the growth of other microorganisms in the environment (CAO et al., 2013).

Bacillus subtilis is one of microorganisms used in such inoculums that impair the growth of enteric pathogens such as Salmonella and Clostridium perfringens (LEE et al., 2010; THIRAUNYANON \& THONGWITTAYA, 2012; SU-YEON \& HYEONG-EUM \& YONG-SUK, 2017), reported a natural competition site between this bacterium and natural pathogens of dairy cattle manure, forming a competitive environment for nutrients and space for cell attachment, while it does not affect the growth of other non-pathogenic bacteria of the same genus as B. licheniformis and B. amyloliquefaciens, which satisfy the condition of synergistic interaction with other species that make up the inoculum.

Other microorganism in the inoculum that might have caused the observed effect in this study is Lactococcus lactis, which produces metabolites during its growth such as nisin, a bacteriocin that prevents the growth of Gram-positive bacteria such as Clostridium and Bacillus (LEE et al., 1999, ASADUZZAMAN \& SONOMOTO, 2009).

It is also known that Bacillus amyloliquefaciens, present in the inoculum, inhibits the growth of thermotolerant coliforms, Salmonella typhimurium and Staphylococcus aureus, by producing antibacterial substances. Another producer of secondary metabolites having antagonistic effect on pathogens is Bacillus licheniformis, which produces bacillocina 490 (CLADERA -OLIVEIRA, CARON \& BRANDELLI, 2004; HE, CHEN \& LIU, 2006).

Thermotolerant coliform such as Escherichia coli is the microorganism that indicates specifically a contamination of fecal 
origin, as it is able to thrive in adverse environment (PARUCH \& MAEHLUM, 2012; SCHWAIGER et al., 2012).

The inoculum used can be considered environmentally safe because it is formed by saprophytic and non-pathogenic microorganisms widely found in the environment (CLAUS \& BERKELEY, 1986).

Nevertheless, the inoculum improved the sanitary quality of the manure and promoted the maintenance of non-pathogenic microbiota. However, in FS, one of the causes of the decrease in pathogen counts might be a greater concern for health by using some more effective products for microbial elimination. The absence of sulfite reducing Clostridium in PMR and HR sites can be attributed to a physical removal of matter present in animal paws.

Pathogen control by enhancing the environmental pressure seems to be an alternative strategy to the use of antimicrobials in disease control in dairy cows. However, further studies are required about health aspects for successful implementation of this technique.

\section{Conclusions}

With the data obtained in this study, we conclude that inoculum application interferes indirectly the physicochemical characteristics of milk and directly SCC, by promoting health quality in the system. In this way, the inoculum was also effective in reducing pathogen populations and might be used as a prevention tool for environmental diseases in dairy farms.

\section{Acknowledgment}

The authors acknowledge the Coordination for the Improvement of Higher Education Personnel (CAPES) for the granting of scholarships for undergraduate and graduate students who participated in this study, which made this work possible.

\section{References}

AMERICAN PUBLIC HEALTH ASSOCIATION (APHA). Compendium of methods for the microbiological examination of foods. 4th ed. Washington: APHA; 2001.

ASADUZZAMAN, SM; SONOMOTO, K. Lantibiotics: Diverse activities and unique modes of action. Journal of Bioscience and Bioenginnering. 2009; 107 (5), 475-487

BRAZIL - Ministry of Agriculture, Livestock and Supply. Normative Instruction №. 51. Brasília (Brazil): Ministry of Agriculture, Livestock and Supply; 2011.

BRAZIL - National Health Surveillance Agency - ANVISA. Resolution RDC №. 12. Brasília (Brazil): National Health Surveillance Agency January; 2001.

BRAZIL - National Health Surveillance Agency, ANVISA. Rule №. 15. Brasília (Brazil): National Health Surveillance Agency January; 1988.

CAO, Y; CHANG, Z.; WANG, J.; MA, Y; FU, G. The fate of antagonistic microorganisms and microbial substances during anaerobic digestion of pig and dairy manure. Bioresource Technology. 2013; 136, 664-671.

CLADERA-OLIVERA, F; CARON, GR; BRANDELLI, A. Bacteriocin-like substance production by Bacillus licheniformis strain P40. Letters Applied Microbiology; 2004; 38, 251-256.

CLAUS, D; BERKELEY, RCW. Genus Bacillus Cohn 1872, 174AL . In: Sneath, PHA.; Mair, NS.; Sharpe, ME.; Holt, JG. (Eds.) Bergey's Manual of Systematic Bacteriology, vol. 2, The Williams \& Wilkins Co., Baltimore, 1986, pp. 1105-1139.

DUFOUR, S; FRÉCHETTE, A; BARKEMA, HW; MUSSEL, A; SCHOLL, DT. In review: effect of udder health management practices on herd somatic cell count. Journal of Dairy Science; 2011; 94,563-579.

HARMON, RJ. Physiology of Mastitis and Factors Affecting Somatic Cell Counts. Journal of Dairy Science; 1994; 77 (7), 2103-2112. 
International Committee for Animal Recording (ICAR). Guidelines approved by the General Assembly held in Riga, Latvia. On 31.05 to 04.06.10. Roma. 2011; 229-256.

HE, L; CHEN, W; LIU, Y. Production and partial characterization of bacteriocin-like pepitdes by Bacillus licheniformis ZJU12. Microbiological Research; 2006; 161, 321-326.

KHALID, K; KIONG, LH; CHOWDHURY, ZZ; KHALID, K. Antimicrobial interaction of Lactococcus lactis subsp. lactis against some pathogenic bacteria. Journal Bioscience; 2011; 1, 39-44.

LADEIRA, SRL. Mastitis Bovina. Diseases of Ruminants and horses. Sao Paulo - Brazil: Library Varela; 2001;1 426

LEE, HJ; JOO, Y.J; PARK, SC; KIM, SH; HWANG, IK; AHN, JS; MHEEN, TI. Purification and characterization of a bacteriocin produced by Lactococcus lactis subsp. lactis H-559 isolated from Kimchi. Journal of Bioscience and Bioengineering; 1999; 88, 153-159.

LEE, NK; YEO, IC; PARK, JW; KANG, BS; HAHM, YT. Isolation and characterization of a novel analytic from Bacillus subtilis SC-8 antagonistic to Bacillus cereus. Journal Bioscience and Bioenginering; 2010; 110,298-303.

LEVY, EC. (2004). Clinical Microbiology Manual paragraph Infection Control in Health Services; 2017 Jul 28 [cited 2004]. Available from: http://www.wpro.who.int/publications/docs/practical_guidelines_infection_control. pdf

MÜLLER, EE. Milk quality, somatic cells and prevention of mastitis. In: Symposium on sustainable dairy farming in southern Brazil, Toledo. Proceedings of the II South - Milk: Symposium on Sustainable Dairy Cattle in southern Brazil, Maringá: UEMCCA/ DZO - NUPEL; 2002, 206-217.

PARUCH, AM; MAEHLUM, T. Specific features of Escherichia coli that distinguish it from coliform and thermotolerant coliform bacteria and define it as the most accurate indicator of faecal contamination in the environment. Ecology Environment Indicators; 2012; 23, 140-142.

RADOSTITS, OM; GAY, CC; BLOOD, DC; HINCHCLIFF, KW. Veterinary Clinic: A treaty of bovine diseases, sheep, pigs , goats and horses. 9th ed. Rio de Janeiro: Guanabara Koogan; 2002.

REIS, GL; ALVES, AA; LANA, AMQ; COELHO, SG; SOUZA, MR; CERQUEIRA, MOP; PENNA, CFAM; MENDES, EDM. Procedures of individual raw milk sampling and their influence on physico-chemical composition and somatic cell count. Rural Science; 2007, 37(4), 1134-1138.[in Portuguese].

SABEDOT, MA; POZZA, MS; SILVA, LS; ZAMBOM, MA; POZZA, PC; ECKSTEIN, II. Isolation of bacteria associated with mastitis and correlation between physicochemical quality and somatic cell count. Journal of Veterinary Science and Public Health; 2014, 1(2),99-106[in Portuguese].

SANTOS, AKR; LEITE, MO; FONSECA, LM; CEQUEIRA, MOP; SOUZA, MR; PENNA, CFAM; MOURA, MRA. Comparison of the Baird-Parker agar, Baird-Parker-RPF and Petrifilm Staph Express in the detection and enumeration of Staphylococcus coagulase positive in raw milk. Journal of Dairy Science; 2010, 93, 603.

SCHWAIGER, K; HUTHER, S; HOLZEL, C; KAMPF, P; BAUER, J. Prevalence of antibiotic resistant enterobacteriaceae isolated from chicken and pork meat purchased at the slaughterhouse and at retail in Bavaria, Germany. International Journal of Food Microbiology; 2012, 154, 206-211.

SHARMA, K; SHINGH, NK; BHADWAL, MS. Relationship of somatic cell count and mastitis: An overview. Asian-Australian Journal of Animal Sciences; 2011, 24(3), 429-438.

SHOBHARANI, P; PADMAJA, RJ; HALAMI, PM. Diversity in the antibacterial potential of probiotic cultures Bacillus licheniformis MCC2514 and Bacillus licheniformis MCC2512. Research Microbiology; 2015, 166(6), 546554. 
SU-YEON, K.; HYEONG-EUM, K.; YONG-SUK, K. The potentials of Bacillus licheniformis strains for inhibition of $\mathrm{B}$. cereus growth and reduction of biogenic amines in cheonggukjang (Korean fermented unsalted soybean paste). Food Control; 2017, 79,87-93

THIRABUNYANON, M; THONGWITTAYA, N. Protection activity of a novel probiotic strain of Bacillus subtilis against Salmonella enteritidis infection. Journal of Veterinary Science and Public Health; 2012, 93 (1),74-81.

XAVIER, CAN; LUCAS, JJ. Scaling of parameters for batch digesters operated with manure of dairy cows with and without inoculum. Agricultural Engineering. São Paulo: Jaboticabal; 2010, 30(2), 212-223.

Pamela Lais Cabral Silva
Universidade Federal de Pelotas
Centro de Engenharias, Email: pamela_lais@hotmail.com
Participated in the field (sample collection), methodology for analysis, data analysis
and interpretation of results.
Thayli Ramires Araújo
Universidade Federal de Pelotas
Postgraduate Program in Food Science and Technology, Email: thayliraraujo@gmail.com
Participated in the field (sample collection), methodology for analysis and
interpretation of results.
Lucas Guidoni
Universidade Federal de Pelotas
Participated in the field (sample collection) and interpretation of results.
Fernanda Gonçalves
Universidade Federal de Pelotas
Mercosur Integration Center, Email: fmgvet@gmail.com
Participated in the interpretation of results.
Roger Marque
Universidade Federal de Pelotas
Food Technology, Email: rogermarquesea@gmail.com

Participated in the methodology for analysis, data analysis and interpretation of results review and approval of the final paper.

\section{Lauren Vieira}

Universidade Federal de Pelotas

Postgraduate Program in Food Science and Technolog, Email: vieira.lauren@yahoo.com.br

Participated in the interpretation of results, english translation and review. Luciara Bilhalva Corrê

Universidade Federal de Pelotas

Engineering Center, Email: luciarabc@gmail.com

Participated in the interpretation of results, review and approval of the final paper. Érico Kunde Corrêa

Universidade Federal de Pelotas

Engineering Center, Email: ericokundecorrea@yahoo.com.br

Participated in the methodology for analysis, data analysis, interpretation of results, review and approval of the final paper. 